\title{
Chapter 19 \\ Social Protection, Marginality, and Extreme Poverty: Just Give Money to the Poor?
}

\author{
David Hulme, Joseph Hanlon, and Armando Barrientos
}

\begin{abstract}
Social protection programs, especially cash transfer programs, have spread across low- and middle-income countries since the beginning of the millennium, and are increasingly part of national development strategies to assist the poor and particularly the poorest. This chapter lays out a wide range of debates about the specific goals, targets, and conditions of social protection and cash transfers. While there is no single best program option, the authors identified five overriding principles for effective efforts. Thus social protection programs and cash transfers work best when they are: fair, assured, practical, large enough to impact household income, and popular. These principles need interpretation at the national level, because no model can be automatically transferred from one country to another.
\end{abstract}

Keywords Unconditional cash transfers • Trust • Empowerment • Poverty

\subsection{Introduction}

Social protection programs, especially cash transfer programs, have spread across low-income and middle-income countries since the beginning of the millennium and are increasingly part of national development strategies (Hanlon et al. 2010). ${ }^{1}$

\footnotetext{
${ }^{1}$ This chapter builds on and updates Chapter 10 of Hanlon et al. (2010).

D. Hulme $(\bowtie) \cdot$ A. Barrientos

Brooks World Poverty Institute, University of Manchester, Manchester, UK

e-mail: david.hulme@manchester.ac.uk; armando.barrientos@manchester.ac.uk

J. Hanlon

Visiting Senior Fellow, Department of International Development,

London School of Economics, UK

Honorary Research Fellow, School of Environment and Development, University of Manchester, UK

e-mail: Joe.hanlon@open.ac.uk
} 
When the Millennium Development Goals (MDGs) were being set in 2000-2001 social protection was barely mentioned. Ten years later in 2010 at the United Nations "MDGs + 10 Summit," sessions on every one of the eight goals referenced social protection programs as a means of achieving poverty reduction targets. ${ }^{2}$

In the short term, well-designed social protection programs reduce poverty levels and ameliorate related suffering, particularly among the poorest (Barrientos and Hulme 2008). In the mid-term they allow many poor people to exercise their agency and pursue micro-level plans to increase their productivity and income. In the longer term, they create a generation of healthier and better educated people who can seize economic opportunities and contribute to broad-based economic growth. Additionally, when sudden crises spread across the world—as with the 2008 triple whammy of global food, fuel and financial crises - these programs help poor families cope with the unpredicted consequences of globalization.

Expanding across the Global South is a heterodox analysis that sees welldesigned social protection schemes as contributing to several goals at the same time. Brazil, Mexico, South Africa, India, Indonesia, and China are paving the way, but the idea is spreading via a genuinely southern revolution. ${ }^{3}$ The focus is on trusting the poor to use money wisely and to pursue objectives that poor people already want to do-send their children to school, improve their diet, and make small investments to increase their income. Cash transfers work especially well when money is targeted at a relatively large group of people and is perceived as social assistance.

Aid donors from developed nations, now calling themselves development partners, have responded after seeing that cash transfers have become an important part of social protection and increasingly recognize them as a legitimate development strategy. Aid donors and some elites in developing countries (especially ministers of finance and business elites), however, have much less trust in the poor. They tend to use terms like "safety nets," "handouts," and "doles" derogatorily, and to view transfers as temporary or short-term solutions, rather than strategic elements that can help raise agricultural productivity, support micro-enterprise, and foster economic activity in marginalized regions. From the USA, where the poor are often blamed for their poverty, the tendency is to emphasize the centrality of conditions-such as school attendance for recipients' children or engaging in public service-rather than to recognize conditionality as one design element of a program. Some programs work better with conditionality while others do not. Schady, one of the authors of the World Bank report Conditional Cash Transfers (CCTs) is a strong advocate of conditions because he is convinced that the problem is the "persistently misguided beliefs" of the poor (Fizbein and Schady 2009, 9). ${ }^{4}$ Indeed in the USA, many specialists are not aware that unconditional cash transfers are a major element of social

\footnotetext{
${ }^{2}$ Hulme attended the MDGs +10 Summit and witnessed this by agencies keen to incorporate social protection, social floors, and conditional cash transfers into future strategies.

${ }^{3}$ During the preparation of this manuscript Hulme was working with the government of Bangladesh on a national social protection strategy and the Asian Development Bank reviewing the "silent revolution" of social protection policy that has swept across Asia.

${ }^{4}$ Speaking at a meeting in London on May 26, 2009.
} 
protection strategies across Asia and Africa: they talk only of CCTs because in the USA the general assumption is that all transfers must be conditional.

From Europe and especially from European donors, there is less suspicion of the poor and greater support for social protection and unconditional cash transfers, but also a tendency to view cash transfers as welfare or antipoverty measures, rather than as an essential component of national developmental strategies. The emphasis of European development efforts is on targeting to minimize expenditures and to ensure that the ultra-poor are the main (or only) beneficiaries, because poverty reduction rather than national development is often the goal.

These three tendencies (Global South, USA, and European) reflect different responses, both to recent economic crises and to the centrality of market-led development. Back in 1944 the renowned economic historian Polanyi outlined what he called the "double movement" in the development of modern capitalism. The "self-regulating market" was promoted by governments with a host of special legislation and it did bring growth, but this free market could not work for labor and the environment. Low wages and unemployment created poverty and misery on a large scale, leading to the counter movement for "social protection," which was increasingly supported in society, forcing governments to intervene in markets (Polanyi 2001; Putzel 2002). The failure of structural adjustments made in the 1980s and early 1990s to promote economic growth in low-income countries, and of "social funds" to protect the poor and newly poor from capability depleting vulnerabilities, showed that palliative approaches to social protection were ineffective. The lack of development and the growth of poverty outside of China and India, culminating in the 1997 Asian financial crisis, demonstrated the failures of neo-liberalism and the "Washington Consensus," and brought the second part of the double movement - the push for social protection. The northern response, epitomized by the MDGs, provides a real increase in social spending and strict social targets for health and education, but also kept governments at arm's length from the economy. The southern response, with Brazil's Bolsa familia as a classic example, has been cash transfers that shift the emphasis to providing poor people with the money necessary for them to take actions to end their own poverty and make greater use of economic opportunities. ${ }^{5}$

Mexico, Brazil, and South Africa introduced large-scale social protection programs in the late 1990s in a Polanyian response to the harm being done by a sole focus on the market as the answer to all development problems. This was a challenge to the Washington Consensus, because the programs were (and are) redistributive and involve governments reallocating resources within countries. The initial response from the North was criticism and the commissioning of studies (Barrientos and Hulme 2008). These studies found that social protection programs worked and that cash transfer programs (with and without conditions) performed particularly well. They reduce both immediate and intergenerational poverty, stimulate the economy, and promote development-especially in marginal rural areas as shown in South Africa (Samson et al. 2004).

\footnotetext{
${ }^{5}$ Brazil, Bolsa Família, see “A Biblioteca Virtual do Bolsa Família," at http://www.ipc-undp.org/mds.do
} 
Word of the success of the three trailblazers has spread across the Global South. ${ }^{6}$ At least 45 countries now have cash transfer programs, providing financial support to more than 110 million families (Barrientos and Hulme 2010). Immediate poverty is being reduced by these efforts. Hundreds of thousands of children are now in school because their families can afford to buy them shoes and school clothes, and can get by without the few pennies the children could earn if kept out of school. Families are also investing small amounts to raise their own income with, for example, cash transfers in rural Africa frequently being used to purchase fertilizer. These programs are still young and this is a global learning exercise. Experiences are being shared among continents; research and experimentation are leading to rapid modifications and improvements in similar programs. Serious analysts also recognize that this is not a quest for the "optimal program," but a contribution to the evolution of national social protection systems that need to be able to improve their performance, maintain political support, and adapt over time in response to changes in national problems and the international context.

The influence of the USA and European tendencies on the development of southern programs varies from country to country, but key patterns can be recognized. In middle-income and larger countries domestic policy makers can "listen" to the USA conditionality and European targeting tendencies, and then decide how best to deal with these from a position of relative autonomy. In lower-income countries and in particular those that are smaller and aid dependent, the degree of autonomy is restricted and there is a real danger that the policies selected derive from external debates rather than being part of a nationally-owned policy discussion. The danger of aid donors dominating national policy formulation about social protection becomes a real prospect in such cases. Where there is a national political consensus on an action, however, it can be pushed through despite donor concerns.

\subsection{Building Local Support}

Building the required local political consensus for change is critical, but can be complex and will surely be different in each country. Political elites need to champion the role that effective social protection can play in national development, and the economic and business elites at least need to recognize the legitimacy of social protection and cash transfers. Debates at the global level are also reflected nationally. The wealthier in poor countries often hold the attitudes of Victorian Britain, blaming the undeserving poor for their poverty. These attitudes have been reinforced by three decades of neoliberalism, which promoted the idea that it was "good" to get rich. A study of economic elites in five southern countries found a consensus that "trickle

\footnotetext{
${ }^{6}$ The achievements of programs in Mexico, Brazil, and South Africa were rapidly and widely disseminated. Other successful programs such as Bangladesh's Secondary School Stipend for Girls (basically a conditional cash transfer to increase female participation in secondary education), were not so well "marketed" and other Asian successes are much less reported.
} 
down" growth-growth in the economy as a whole working its way down to the poorest-would eventually end poverty and that education was the most important means for improving the welfare of the poor (Reis and Moore 2005).

In a study of economic elites in Malawi, some admitted that they actually benefit from poverty (Kalebe-Nyamongo 2009). The poor provide cheap labor and votes, as well as jobs in the aid industry. However, there was not a perception among the elite in Malawi that the poor are lazy, and thus there was not a distinction between "deserving" and "undeserving" poor. Nevertheless the elites believed that poverty will never be reduced and that the poor were responsible for their own poverty- that the poor do not work hard because they are resigned to poverty as a normal way of life - and thus the elites worried that cash transfers create dependency. This may be reflective of Malawi's experience with a very narrow cash transfer program that only targeted the labor constrained ultra-poor. In the mid-2000s the government's preference for a fertilizer subsidy program for small farmers, rather than a cash transfer program for the poor, reflected the elitist view that people should be encouraged to work (to its credit, the subsidy did raise productivity and improve household food security very quickly).

By contrast in Brazil only $1 \%$ of a sample of 311 members of the economic elite blamed poverty on a lack of effort by the poor (Reis 2005, 2009). Nearly half blamed a lack of state efforts or the lack of political will, and most elites believed that the state has a responsibility to provide for the poor. Brazilian elites view poverty and inequality as problems, and are particularly concerned about their relationships with criminal violence. Perhaps it is not surprising in a country where the poor are not blamed and the state is given responsibility, that Brazil has taken a global lead in designing innovative social protection programs (including the systems that allow them to work well, such as unique identification and national-level data coordination) and in financing cash transfers.

Politics are important, and effective social protection programs can only be introduced when a critical mass of support can be created. Hickey (2006) makes the point that civil society does not seem to play an important role in the introduction of cash transfer programs in Africa because the old, the poor, and the weak do not constitute politically active pressure groups. Thus it becomes essential to mobilize support within government, parliament, and political parties, and to use the electoral process. It is necessary to tap into the social responsibility attitudes of the business and social elites, and to convince both the elites and the middles classes that social protection programs are in their best interest-they will help create the conditions that the elites want, i.e., growing economies and more cohesive societies. The general shift from a narrow welfare approach targeting only the poorest to a broader developmental approach that views social protection, not as poverty reduction but as national development, seems likely to make it easier to gain support.

Within governments, transfers (whether cash or in-kind) are often the responsibility of administratively and politically weaker ministries that deal with social welfare or support for women and children. Finance and economic development ministries, which typically have more political and intellectual clout inside governments, need to address social protection as an essential component of social 
development programs. That in turn means making the case that cash transfers are not just instruments for mitigating current poverty, but are profitable investments in long-term development that are as effective as roads and dams (indeed more effective than many dam projects that are often completed vastly over budget and under capacity).

Why do low-income governments often prefer fertilizer subsidies to social welfare programs? Why do donors appear to prefer welfare programs to fertilizer subsidies? Governments tend to view enhanced access to agricultural inputs as an investment in production, food security, and economic growth. Conversely they often regard welfare handouts to widows and orphans as an unaffordable luxury that generates apathy and dependency among the poor. A great deal of effort has been expended trying to convince skeptical governments (especially among finance ministries) that they are wrong about cash transfers, which can achieve poverty reduction and generate economic growth, but do not necessarily generate dependency. This argument, however, is not yet won according to Devereux (2009).

Making the case for social protection in low-income countries requires making it look politically attractive as well as fiscally affordable, to stakeholders who have to commit to it and will eventually have to pay for it. Politicians are more interested in evidence that social protection will win votes than in evidence that it reduces poverty

This point is underlined in a study of drought relief efforts in Africa by Munemo (2008), who examined why some governments have preferred universal food aid while others - or the same governments at different times-have opted for workbased relief schemes. Munemo finds, not surprisingly, that incumbent governments that are vulnerable to the loss of political power tend to prefer measures with immediate benefits for a broader base of voters. Political groups that are more secure in their position can afford to opt for programs that are more targeted on smaller groups and that are developmental with longer temporal horizons.

Political and even patronage power need to be mobilized in support of social protection programs. This will vary radically among countries. For example both China and Brazil have decentralized their cash transfer programs to municipalities, which allows local elected officials to take the political credit. By contrast, in Bangladesh political parties and politicians are loath to provide social protection programs in urban areas where they do not convey influence over voting behaviors in the ways that social protection efforts in rural areas do.

Public attitudes are important and the media affect the way that people think. The prevalence of articles about "welfare scroungers" contributes to a climate that stresses the "undeserving poor," while articles about rising school attendance and new businesses begun on a shoestring —although less common—support approaches designed to give people the economic security they need to take the risks and make the micro-investments that lift them out of household poverty traps. There is also a mutually reinforcing relationship between political leadership and media coverage.

In Ghana the Ministry of Manpower did not wait for media coverage, but instead launched a strong advocacy media campaign to explain to the public that giving money to poor people is not about "handouts," but rather about support for children, 
the elderly, and those who are not able to work (Sultan and Schrofer 2008). In a study of non-contributory pensions for the Chronic Poverty Research Centre in Lesotho, Namibia, and South Africa, Pelham (2007) concluded that successful programs built a bond between citizens and the state based on three factors - social solidarity linked to the value and contribution of the elderly in the household, the understanding that pensions are a permanent program that can be depended on, and acknowledgment of the role of the state in securing the welfare of its citizens. Local and global events can play important roles in creating change and openings for the introduction of social protection policies. The Zapatista rebellion in Mexico, the end of apartheid in South Africa, and the end of the military dictatorship in Brazil all created space for policy changes. Hickey $(2006,25)$ points to the way social protection policies come to the fore "when the social impacts of liberalized capitalist economies become too great to be borne in political terms," which was happening in Brazil and Mexico_- the other half of Polanyi's double movement.

Hickey's research underlines the importance of electoral politics. Political parties attempting to stay in power or win power can use cash transfers to win new constituencies or to strengthen existing ones. The balance can be quite complex. Middle class support is essential, and Hickey points to the need to include not just the very poorest. Programs which benefit the middle class are more likely to win support. Fairness, justice, and social responsibility seem to be important, but are often relatively intangible elements of such political processes.

Brazil provides a particular example of the political dynamics at work. Brazil had come out of the 1964-1988 period of military dictatorship and the 1988 constitution stipulated poverty alleviation as a role of the state. The idea of a child benefit as a first step toward a basic income was proposed by the Workers Party [Partido dos Trabalhadores (PT)] and entered public debate. Because of decentralization in Brazil, the idea was first picked up by municipalities and by 1998 , 60 municipalities and four states had introduced a variety of child benefit programs. Fernando Henrique Cardoso was running for re-election as national president in 1998 against the PT's Luiz Inácio Lula da Silva ("Lula"), so he adopted the child benefit (as the Bolsa Escola school grant) as a national program. Cardoso won a second term and Bolsa Escola was scaled up. Lula subsequently won the presidential election in 2002 and expanded the program as the Family Grant (Bolsa Família) (Melo 2007).

Expanding the program increased Lula's popularity and he was re-elected in 2006. "I like Lula a lot-he gave us Bolsa Família. Many people today have a better life," Selma Aguiar who runs a luncheonette in Vale do Mearim in the state of Maranhão later told BBC Brazil (Corrêa 2009). "He has improved our life, and that of many families, a lot. I receive R $\$ 122$ [US\$67] per month. I voted for Lula and I will vote for him again," added Eliene da Silva Brito, a farmer with five children.

In Lesotho the government was re-elected in 2008, in part because of the popularity of the pension introduced in 2004. In Mexico the cash transfer not only survived the historic change in the government of Mexico in the 2000 elections, but the new administration of President Vicente Fox expanded its coverage from rural to 
urban poor areas of the country, renaming it from Progresa to Oportunidades. ${ }^{7}$ The program was politically popular because of the overwhelming and unprecedented evidence that it was alleviating poverty and encouraging the rural poor to send their children to school (Skoufias 2005). In an opinion survey conducted in South Africa, exactly two-thirds of the population agreed with the statement "the government should spend more money on social grants for the poor, even if it means higher taxes" (Noble et al. 2008). Perhaps more importantly taxpayers also agreed-the statement had the support of $59 \%$ of the poor and $63 \%$ of paid workers. So in South Africa social grants also win votes. In Bangladesh the incoming Awami League government of 2009 cancelled the predecessor government's "100 days work" cashtransfer scheme, but immediately launched a new but similar scheme so as not to lose political popularity.

Globally, social pensions seem to be the most popular programs for national governments: they are inclusive, satisfy instinctive desire to support the elderly, are good value, and are perceived as fair. For purely selfish reasons voters are attracted to the idea of universal pensions because it provides some peace of mind regarding one's own fate, or that of a grandparent, aunt, friend, or neighbor, during old age. Finance and social welfare ministries also recognize that older people spend a significant part of their pension on children and others in the household, so pensions have a broader demographic impact. Child benefit programs, as in the case of South Africa, have similar broad appeal.

It appears that social protection programs, and especially cash transfers, can start small. Successful programs, however, are not narrowly targeted at specific groups with whom most voters cannot identify. They are established in a way that makes expansion obvious and possible - targeted on the poorest districts or individual municipalities which makes expansion to other districts a political goal, or targeted at poor children which makes expansion to a comprehensive child benefit seem reasonable.

Nicaragua's donor financed "Social Protection Network" [Red de Protección Social (RPS)] showed what can happen to a program without broad support. Its first phase from 2000 to 2002 was spectacularly successful, improving nutrition, health, and school attendance rates (Moore 2009). For its second phase during 2002-2005, however, cash payments were cut from US\$19 per family a month to US\$12. Although the second phase was also successful, the program was abandoned in 2005 by the government, even though continued funding was available. It was a textbook case of how not to design a popular program. First, in order to ensure that the program was not seen as "welfare," it never mentioned poverty reduction as one of its goals. Instead the cash was presented purely as a way of buying behavioral change of the poor in order to build human capital and thus had no buy-in from the vast majority of people, who felt they already knew how to look after their children

\footnotetext{
${ }^{7}$ See Mexico-Oportunidades external evaluations in English at http://evaluacion.oportunidades. gob.mx:8010/en/index.php and in Spanish at http://evaluacion.oportunidades.gob.mx:8010/es/ index.php
} 
and thus would never benefit. Second, the program was almost entirely driven by the Inter-American Development Bank (IDB) and by a small group of key civil servants with experience in World Bank and IDB programs within the Emergency Social Investment Fund [Fondo de Inversión Social de Emergencia (FISE)].

Program administrators were under a large amount of pressure from the IDB to implement the RPS quickly, so they did not have time to build political support in congress with then President Enrique Bolaños and his Constitutional Liberal Party (PLC) or with the opposition party (Frente Sandinista de Liberacion Nacional) and their leader Daniel Ortega who was subsequently elected president in 2006 and was openly opposed to the RPS. Although there was international praise for the program, there was little domestic publicity for its success. Finally RPS proponents even failed to build support within the civil service. In 2002 it was moved from the FISE to the weaker Family Ministry, where there was discontent about the higher, donor funded salaries of the RPS staff. It was the family minister who decided in 2005 not to continue the RPS despite continued availability of the IDB funds.

Honduras provides another example of the dangers of a small and politicized program. Honduras has been experimenting with its family grant program [Programa de Asignación Familiar (PRAF)] for more than a decade. It was too small, however, to gain widespread support and created competition between the IDB and the government. Beneficiaries were often chosen on political grounds rather than on need. Newly elected presidents in both 2002 and 2006 dismissed the entire PRAF staff and appointed new people. Not surprisingly PRAF became identified as a political project of the governing party (Moore 2008; Osório 2008). Nicaragua and Honduras are, however, exceptions to a broader pattern. Where Southern governments have been able to take the lead and build a political consensus reflecting local conditions and history, programs are generally proving popular, effective, and durable.

\subsection{Cash Transfers Work}

Cash transfers can provide the essential boost necessary to lift people out of the poverty trap - they can be the proverbial boots that allow people to pull themselves up by their bootstraps. Virtually all evidence supports the conclusions that people typically spend the assistance money in meaningful ways and that the grants do not encourage people to be lazy or avoid work (Hanlon et al. 2010). For most poor people a lack of money is their biggest problem. Small farmers in Malawi do not need agricultural extension workers to tell them to use fertilizer on their maize, they need US $\$ 3.50$ to buy half a bag of subsidized fertilizer. The Oportunidades program recipients in Mexico have convinced even policy makers that they already knew how to make profitable investments and that all they needed was the money. Giving people money is proving to be amongst the best ways to stimulate local economic development in low-income countries. Social protection and cash transfers are not social programs that can wait until after economic growth has been achieved, instead they are an essential precursor to growth and a driver of development. 
Vuyiswa Magadla lived in a tiny house at the end of an alley in the Khayelitsha township of Cape Town, South Africa. She had diabetes and could not walk much or see well, and received a disability grant. She continued to work selling fruit and vegetables, and used money from her grant to buy fresh vegetables. She may not have been healthy, but she was a good trader and traveled quite far to a place in Nyanga East to buy produce, rather than from Mabhela's wholesale closer to her home where vegetables were not as fresh. Fortunately the minibus driver did not charge her extra for her box of vegetables because she carried it on her lap (du Toit and Neves 2006).

For the poorest, the elderly, and the disabled, cash transfers are essential social welfare that can lift people out of destitution and allow them to buy food for a second meal a day, but the importance of cash transfers is much broader. A key benefit is enabling children to be better off as adults than their parents. This starts with more and better food when they are young, which prevents malnutrition, which is critical because the stunting caused by malnutrition is a mental as well as physical phenomenon, and children who do not develop properly never recapture that lost physical and mental development. Cash also allows children to attend school-they do not have to work to help support their family and money is available for clothes and books. Children who finish secondary school are much less likely to be poor as adults than those who do not. Cash transfers can be a critical investment in the next generation and in the long-term elimination of poverty (Hanlon et al. 2010).

\subsection{The Southern Alternative}

Over the past decade social protection programs and particularly cash transfers have emerged as the response of the Global South to economic development and poverty reduction needs. The Washington Consensus free-market model of the 1980s and 1990s did not bring economic growth and development to most developing countries, but rather often lead to increased poverty and inequality. In the industrialized North, social protection and cash-benefit schemes expanded rapidly in the second half of the twentieth century, but these were largely insurance-based schemes that depended on a household breadwinner with a steady job. In the South, however, most people are small farmers, landless laborers, or are working in informal market sectors and cannot qualify for insurance coverage. The USA variant of the northern model is also built on an inherent distrust of poor people and on the assumption that the poor are a relatively small group - an assumption that is getting harder to support considering that $15 \%$ of USA families required federal food assistance in 2011 (Izzo 2011).

The Global South has been rethinking the problem from the bottom up. Poor people who have struggled to survive on tiny amounts of cash are good economists who use additional money efficiently. Giving money directly to poor people is proving to solve three problems at once. First it alleviates immediate problems associated with poverty; much of the money is spent on more and better food. Second it 
allows poor people to invest small amounts in their farms and small businesses, and all evidence supports the conclusion that ordinary people know how to make profitable investments. Furthermore money is spent locally, which stimulates local economies, increasing local demand and creating an upward economic spiral. Third, poor families can send their better fed children to school, creating a healthier and better educated next generation that will be more able to play an active role in development. The key is to trust the judgment of poor people and to prioritize directly giving them cash - rather than projects, temporary welfare or vouchers (unless there is evidence from experimental schemes that vouchers work better) - money they can invest, use, and rely on. Cash transfers can be a key part of the ladder that lets people climb out of poverty traps. Letting people make their own choices about how to spend money is also empowering.

The late twentieth century was a very conservative period. The North, as well as economic elites in many countries of the South, tended to blame the poor for their poverty, and some still do not believe that poor people are able to act in the best interests of their children. The first southern cash transfer programs began in middleincome countries, which could fund them with their own tax revenue and that were under increasing domestic political pressure to deal with worsening poverty associated with structural adjustment policies. The high degree of distrust meant that these programs have been extensively studied - all the more so when "experts" simply did not believe the initial results showing how well cash transfers were working.

The whole exercise began experimentally, but these programs were big, giving money to millions of families - not just the poorest of the poor, but also to larger groups who were below the poverty line. Each country started its programs differently. Programs were modified in response to initial research, and the ideas and experiences spread as more countries introduced cash transfer programs. Research continued and there was increased sharing of information, experience, and ideas.

One lesson was that cash transfers are not a magic bullet; they do not work on their own. There must be schools and health posts that poor people have access to, as well as to land, improved agricultural technologies, and jobs. The biggest lesson, however, has been that people must have the minimum amount of money necessary to take advantage of schools, health facilities, and land. If they do have sufficient money, they can take the lead in their own development.

\subsection{Northern Responses and Opportunities}

Middle-income countries, particularly Mexico, Brazil, and South Africa pioneered the development of cash transfers, and their early success led many low-income countries to start programs that attracted donors and international development banks. This increased tensions, because aid donors and international agencies with headquarters in the North worried that simply giving money to the poor would waste their financial aid and for some, reduce their power. Some of the Washington, DC-based institutions, particularly the International Monetary Fund (IMF), refuse to 
trust the judgment of the poor and have tried to retain power by imposing expenditure ceilings and harsh conditions. Some of the European donors find it hard to accept that cash transfers can contribute to development and thus might replace some of their traditional development programs, and therefore tend to support cash transfers only as social welfare.

Northern institutions are trying to catch up, but the initiative and the action remains in the South. The southern model of cash transfers is new, and in a learning culture it is evolving rapidly and it is not just about poverty and welfare. This movement has been conceptualized in the south and has driven a rethinking of development models-give money to the poor because they can be trusted to make better use of it than aid industry project officers and social workers. Lessons are being learned and experiences exchanged. New York is drawing on the experiences of both South Africa and Mexico. Indonesia is also drawing on the experiences of Mexico and Ghana on Brazil's. Pensions have spread from South Africa to neighboring states. South-South cooperation is challenging the established wisdom of Washington and London as ideas diffuse from Brazil, India, Mexico, and elsewhere.

Just as cash transfers in the South have been mold-breaking, however, the most interesting responses in the North have come from outside the normal aid and development network. US President Barak Obama specifically invited Indonesian President Susilo Bambang Yudhoyono to speak at the G20 meeting in Pittsburgh in September of 2009 to promote his policy of phasing out fuel subsidies and giving the money to the poor via cash transfers instead. It was an unexpected convergence of several policy lines. From a climate change perspective Obama was promoting an end to fossil fuel subsidies. Just 2 months beforehand Yudhoyono had been reelected president with more than $60 \%$ of the vote, and his landslide victory was credited in part to increased support from the poor through cash transfers (Harvey and Luce 2009; Perry 2009). Thus climate change, democracy, and cash transfers to help the poor are coming together in a new way.

One question often raised is how social assistance transfers can be delivered. Cash transfers provide an obvious solution. The most important point is that successful cash transfers are both locally designed and transparent-local people make the choices about targeting and whether or not to impose conditions, but the distribution of funds is much easier to audit than conventional aid funded development projects. Thus northern taxpayers and donors could be more adequately assured that their money was being distributed to children or poor families or the elderly.

Although the poorest countries, particularly in Africa, can afford limited cash transfer programs with their own resources, these programs will need outside financial support for years to come in order to be effective. The shift in thinking, away from conventional aid projects toward budget support and block grants, points to cash transfers as the most effective way to distribute social assistance money-reducing poverty while promoting development, and (if skillfully designed) slowing climate change and reducing the likelihood of another financial crisis. 


\subsection{Five Principles}

This chapter (and our book Just Give Money to the Poor) has laid out a wide range of debates about the specific goals, targets, and conditions of social protection and cash transfers. ${ }^{8}$ Each country is developing its own model that reflects its own needs, history, and politics. There is no single "best" program option, but we can outline five overriding principles. Social protection programs and cash transfers work best when they are: fair, assured, practical, large enough to impact household income, and popular.

Fair. Transfers and grants must be perceived as fair, in that most citizens agree on the choice of who receives money and who does not. Categorical grants-giving to all or nearly all children or elderly_are usually seen as fair, but may not always target the neediest. A strategy of excluding the better off, as used in Brazil and South Africa, is sometimes seen as fairer than trying to distinguish between shades of poverty. Targeting the poorest or the ultra-poor requires much more care, because it can be divisive and create conflict between neighbors when some receive support grants and others do not. Proxy means tests may be relatively accurate, but they are not easily understood by beneficiaries. There is also the problem of poverty dynamics. A household identified as poor 3 months ago (when the household head was sick and unable to work) may not be poor today. The household next door, identified as not being poor 3 months ago may now facing destitution after recent floods washed away its property.

Assured. Recipients must be certain that every month the money will arrive and that families can depend on it. Only then will families be able to make long-term plans like investments in education and income generation. The insurance function of grants is important because people know that if their crop fails or they fall ill, they will continue to receive some income - and this security allows people to take risks, such as experiment with new crops or travel farther to look for work.

Practical. Directly related to the previous two principles, there must be a system to fairly identify recipients and ensure they regularly receive their grant. This requires sufficient trained civil servants to oversee and audit the system, and a reliable, secure banking or cash distribution system to deliver payments. Sophisticated proxy means tests and complex conditions are of little use if they cannot be applied correctly and consistently. Some countries have much more experienced civil services than others

\footnotetext{
${ }^{8}$ Other useful websites include: the United Nations Development Programme (UNDP) International Policy Centre for Inclusive Growth (IPC-IG), formerly the International Poverty Centre, in Brazil has an excellent Cash Transfers and Social Protection archive at http://www. ipc-undp.org/cct.do; the Social Assistance in developing countries database 2007 at http://www. chronicpoverty.org/pubfiles/socialassistancedatabase_version4_august2008.pdfversion 4.0; the Brooks World Poverty Institute, University of Manchester working papers on social protection at http://www.bwpi.manchester.ac.uk/; and the Chronic Poverty Research Centre, University of Manchester research on Insecurity, Risk and Vulnerability at http://www.chronicpoverty.org/ research-themes-vulnerability.php
} 
and some countries, particularly in Africa, may be forced to adopt simpler systems because of a lack of capacity. There are a growing number of effective innovations for transferring cash where civil services are weak: through post offices, lottery agents, and even mobile phones.

Not Pennies. Grants must be large enough to cause a real change in behavior, such as growing new crops or sending children to school. For example, if the amount of money is only enough to let one extra child in the family go to school it may be insufficient. In rural African communities where cash incomes are very low and people produce a significant amount of their own food, even a few dollars a month makes a huge difference in the choices they can make. In more industrialized countries where the cash poverty line and cost of living are higher, it requires more money to make a meaningful difference. Indications are that grants should ideally be not less than $20 \%$ of household consumption and where this level is not met the grants are unlikely to have the desired effect.

Popular. Any social protection or grant program must be politically acceptable and hopefully are popular enough to win votes. Cash transfers are an important step on the road towards achieving social contracts in developing countries, towards replacing conflict and corruption with solidarity and social bonds. Donor initiated and driven programs are less likely to win approval than ones that have indigenous roots, even if they have an "optimal" design they will not have local ownership.

These principles need interpretation at the national level, because no models can be automatically transferred from one country to another. High quality technical analysis is needed alongside the recognition that effective programs need to be based on local political support. Each government will juggle goals and competing demands for resources, and develop its own approach. A decade of experience, however, shows that cash transfers work. To reduce poverty and promote development, just give money to the poor.

Open Access This chapter is distributed under the terms of the Creative Commons Attribution Noncommercial License, which permits any noncommercial use, distribution, and reproduction in any medium, provided the original author(s) and source are credited.

\section{References}

Barrientos A, Hulme D (2008) Social protection for the poor and poorest: concepts, policies and politics. Routledge, London

Barrientos A, Hulme D (2010) Social protection for the poor and poorest in developing countries: reflections on a quiet revolution. Oxford Dev Stud 38(1):439-456

Corrêa A (2009) Desabrigados ainda Reverenciam Lula, mas Ignoram Dilma. BBC Brasil, 29 May

Devereux S (2009) Social protection and the global crisis. Regional Hunger and Vulnerability Programme, Johannesburg

du Toit A, Neves D (2006) Vulnerability and social protection at the margins of the formal economy - case studies from Khyelitsha and the Eastern Cape. United States Agency for International Development and Programme for Land and Agrarian Studies, Cape Town 
Fizbein A, Schady N (2009) Conditional cash transfers. World Bank, Washington, DC

Hanlon J, Barrientos A, Hulme D (2010) Just give money to the poor. Kumarian Press, West Hartford

Harvey F, Luce E (2009) US backs ending of fossil fuel subsidies. Financial Times, 24 September

Hickey S (2006) The politics of what works in reducing chronic poverty, Chronic poverty research centre working paper 91. Chronic Poverty Research Centre, Manchester

Izzo P (2011) Some $15 \%$ of US uses food stamps. The Wall Street Journal, 1 November

Kalebe-Nyamongo C (2009) Elite perceptions of poverty in Malawi. Paper presented at the roles of elites in economic development conference, Helsinki, 12-13 June 2009

Melo M (2007) Political competition can be positive: embedding cash transfer programmes in Brazil. In: Bebbington A, McCourt W (eds) Development success: statecraft in the south. Palgrave Macmillan, Basingstoke

Moore C (2008) Assessing Honduras' CCT Programme PRAF, Programa de Asignación Familiar: Expected and Unexpected Results, Country study 15. International Poverty Centre, United Nations Development Programme, Brasilia

Moore C (2009) Nicaragua's Red de Protección Social: An Exemplary but Short-Lived Conditional Cash Transfer Programme, Country study 17. International Poverty Centre, United Nations Development Programme, Brasilia

Munemo N (2008) Political incumbency and drought relief in Africa. In: Barrientos A, Hulme D (eds) Social protection for the poor and the poorest. Palgrave Macmillan, Basingstoke

Noble M, Ntshongwana P, Surender R (2008) Attitudes to work and social security in South Africa. Human Science Research Council, Capetown. Available at www.hsrcpress.ac.za

Osório R (2008) The recent impact of government transfers on poverty in Honduras and alternatives to enhance their effects, Working paper 47. International Poverty Centre, United Nations Development Programme, Brasilia

Pelham L (2007) The politics behind the non-contributory old age social pensions in Lesotho, Namibia, and South Africa, Working paper 83. Chronic Poverty Research Centre, University of Manchester, Manchester

Perry N (2009) Indonesians choose reformist Yudhoyono. UPI-Asia, 13 July

Polanyi K (2001) The great transformation: the political and economic origins of our time, 3rd edn. Beacon, Boston

Putzel J (2002) Politics, the state and the impulse for social protection: the implications of Karl Polanyi's ideas for understanding development and crisis, Crisis states working paper 1 . London School of Economics, London

Reis E (2005) Perceptions of poverty and inequality among Brazilian elites. In: Reis E, Moore M (eds) Elite perceptions of poverty and inequality. Zed Books, London

Reis E (2009) Poverty and inequality in the eyes of the elites. Paper presented at the roles of elites in economic development conference, Helsinki, 12-13 June 2009

Reis EP, Moore M (2005) Elite perceptions of poverty and inequality. Zed Books, London

Samson M, Lee U, Ndlebe A, MacWuene K, van Niekerk I, Gandhi I, Harigaya T, Abrahams C (2004) Final report. The social and economic impact of South Africa's social security system, EPRI research paper 37. Economic Policy Research Institute, Cape Town

Skoufias E (2005) PROGRESA and its impacts on the welfare of rural households in Mexico. International Food Policy Research Institute, Washington, DC

Sultan S, Schrofer T (2008) Building support to have targeted social protection interventions for the poorest - the case of Ghana. Paper presented at the social protection for the poorest in Africa: learning from experience conference, Kampala, 8-10 September 2008 